\title{
The Construction of SMEs' Innovation and Entrepreneurship Service System under the New Normal of Economy
}

\author{
Tian Gan \\ Yunnan University Dianchi College, Kunming, China \\ 449428955@qq.com
}

Keywords: Technological Innovation; SMEs; Innovation and Entrepreneurship; Service System

\begin{abstract}
With the further development of the social economy, technological innovation occupies an important position in the development of the enterprise and promotes the rapid development of the enterprise. In the process of social and economic development, small and medium-sized enterprises occupy half of the country, affecting the actual results of the development of the national economy. Therefore, it is necessary to speed up the construction of SMEs' technological innovation and entrepreneurship service system. In the process of China's industrial restructuring and transformation, SMEs occupy a certain proportion, and technological innovation plays an important role in the further development of SMEs. The further development of SMEs in turn promotes the rapid development of the national economy. This article needle on China's science and technology innovation service system for small and medium-depth analysis to identify technological innovation and entrepreneurship in the SME service system problems and propose solutions, and constantly improve the service system for SMEs technological innovation and entrepreneurship, promote SMEs The rapid development.
\end{abstract}

\section{Introduction}

With the new development of economy, our country pays more and more attention to the development of science and technology SMEs. We recognize that SME innovation and entrepreneurship have been and will continue to promote the development of China's market economy and economic growth. In order to support the development of innovative companies, China has promulgated many policies aimed at establishing a sound innovation and entrepreneurship service system for these enterprises. At this stage, it is an important transition period for the development of the vast majority of SMEs in China. All relevant policies have tilted preferences to help them successfully complete the transition and gradually move on track. However, China's economic system still has many uncertainties, and it is difficult to maintain stability and coordination. Each company's growth is also flawed, progress is slow, and the quality of transformation is uneven. Some companies cannot operate in accordance with the law, lack the sense of integrity, and market behavior is not very normative. These kinds of problems have affected the healthy growth of 
the company. Furthermore, today's global technology and economic environment also requires the country to take the road of innovation. Enterprises must have independent creativity so as to enhance the international competitiveness of the industry and realize the dream of turning from "manufactured" to "created". However, the current corporate creativity alsogreatly depends on the competitiveness of science and technology. Therefore, if we want to improve the country's overall technological innovation capability, we must start from the company's technological competitiveness, and make it a great improvement. The increase in the competitiveness of corporate science and technology depends on the optimization of the technological innovation and entrepreneurship environment. In order to further optimize the technological innovation and entrepreneurship environment, it is necessary to improve the technological innovation and entrepreneurship service system, enhance the technological innovation and entrepreneurship service capabilities, and accelerate the cultivation of strategic emerging industries.

\section{Support system for innovation and entrepreneurship service for SMEs in the United States}

The United States is a country with a perfect market system. Its system for promoting the development of small and medium-sized enterprises is also fully constructed in accordance with the principles of a market economy. The SME entrepreneurship service support system in the United States involves all aspects of SME entrepreneurship and is a relatively mature and complete system in the world. The service support system is very flexible . It makes corresponding adjustments to the changes in the needs of small and medium-sized enterprises. This is also one aspect of the success of the American SME entrepreneurship service support system. The American SME Entrepreneurial Service Support System is a multi-agency, multi-level, multi-faceted and extensive service system diagram with the SME Authority as the core organization, and it has a wide participation of the whole society .

The U.S. financial services system mainly includes financing services, loan services, complete venture capital exit mechanisms, and preferential taxes. The United States provides strong financial support through direct guarantees to SME loans and investments to guide private funds to set up SME investment companies to directly invest in SMEs.

In the information consulting service system, the U.S. government uses government funds to guide private organizations to set up service centers for small and medium-sized enterprises and information centers for small and medium-sized enterprises to provide various consulting services to small businesses throughout the country. And through the network to establish an e-commerce college, free training and information resources for SMEs. In addition, the U.S. government has also established a "retirement manager service group." Most of the members are retired entrepreneurs and senior executives of the company. They provide travel expenses. They voluntarily provide various management consulting and technical services to small and medium-sized enterprises on a voluntary basis.

In terms of the technical support service system, the U.S. government has formulated a research plan for SMEs' innovation. It has used administrative means to require large organizations to give SMEs the opportunity to participate in technological innovation. It has also formulated a scientific and technological achievements transfer plan and established a small and medium business incubator. Funding means to promote the transfer of technology from large institutions to enterprises.

As for the market expansion service system , the U.S. government has achieved the purpose of helping SMEs to expand their markets through three aspects. 1 , the government procurement contract. SME Bureau annual federal structure and negotiate, to determine the proportion of procurement for SMEs, and business services by country, for the enterprise issued qualification and contract guarantees to help them obtain contracts; 2,take the initiative for large enterprises 
supporting SME Bureau Contact with large companies and provide cooperative support services for small businesses. 3. Set up export support centers for SMEs to provide export support.

\section{The status quo of China's SMEs innovation and entrepreneurship service system}

\subsection{The Service System Model is More Vague}

Mature foreign innovation service system is generally divided into two forms: public and private. Public systems are promoted and supported by government forces. Corresponding institutions and daily routines should be established. Private systems are led by non-governmental forces and promoted through the market. Similarly, similar institutions are set up. They are independent and close at the same time. Contact has formed a complementary whole and is dedicated to doing a good job of innovation. China's innovative service system is only equivalent to the foreign public system. The government-led behavior is obvious, and the role of the private system is almost negligible.

\subsection{The Function of Intermediary Services is Single}

The service industry must provide support and help for enterprises, and must develop and expand a variety of service functions to meet the different needs of various types of enterprises. Western countries' service systems and the services they provide generally change with the needs of innovative companies. For example, there is a research center in the United States, a consulting service center in the United Kingdom, and a project support center in France. China's current intermediary services are relatively simple in function and can only meet the basic requirements of innovative companies, but they cannot provide a wide range of assistance in terms of capital, talents, and technology. This situation is far from meeting the development requirements of China's innovative enterprises.

\subsection{The Operation Mechanism Of Science and Technology Services is Not Perfect}

As there are still many unreasonable factors in the allocation of resources for the service system, there are many restrictions on the market, and the diversification model of the investment subject has not been fully formed. The construction of the social credit rating mechanism is still not complete, and the degree of information management and standardization are both Still relatively low. Technology service agencies are actually carriers of the knowledge industry. However, the current situation is that the boundaries between its and many other trade intermediary agencies are ambiguous. They are also regarded as general business in terms of access to markets, licenses, and management. The characteristics of the enterprise and the industry have not been demonstrated, and there are no special implementation rules to enable them to enjoy the preferential policies of the high-tech enterprises.

\subsection{The Management Team of Innovation And Entrepreneurship Services Lacks High-Quality Talents}

In general, in the innovation and entrepreneurship service system, the required practitioners must not only master the technology, but also have a certain degree of familiarity with the market. Not only must they know the management knowledge, but they must also be able to understand the relevant laws. They should be a type of compound advanced product. Talent. However, in the current situation, the existing service agencies are not large in scale, and the level of specialization 
is not high, and it is difficult to recruit the necessary high-quality talents. Therefore, in the market environment, there is no higher-level talent team, which will inevitably reduce the service level of such institutions, the service items are limited, and the service methods are relatively simple. Without professional service capabilities, it is impossible to meet the needs of various types of customers. All needs, can not get the approval of society and various companies.

\section{Construction and improvement of concrete measures for the technological innovation and} entrepreneurship service system of small and medium-sized enterprises in China

\subsection{Increase government policy support}

In the process of the establishment of SMEs' technological innovation and entrepreneurship service system, SMEs must strive for government policy support, provide a good external environment for technological innovation and entrepreneurship, and promote the further development of SMEs. At the same time, in the process of formulating economic policies, the government must increase the financial support for SMEs in technological innovation and entrepreneurship so that SMEs have a solid backing in the process of technological innovation and entrepreneurship development, and they will be fearless. It is conducive to the smooth progress of SMEs' technological innovation and entrepreneurship.

\subsection{Continuously improve the enterprise management mechanism}

In the process of constructing the SME technology innovation and entrepreneurship service system, it is necessary to further improve the internal management mechanism of SMEs and improve management efficiency. When the service system is running, it is necessary to track and understand in time, grasp the corresponding development of the market economy, and provide corresponding data support for the economic development of the company. In the process of technological innovation and entrepreneurship in small and medium-sized enterprises, we must pay attention to industrial incubating capabilities, so as to provide impetus for the development of enterprises. In addition, it is necessary to optimize the internal management mechanism of small and medium-sized enterprises, pay attention to the management of internal intellectual property rights of enterprises, establish an enterprise information management system, and promote the further development of small and medium-sized enterprises.

\subsection{Build a financing platform for smes}

In the process of the establishment of SMEs' technological innovation and entrepreneurship service system, SMEs need to establish a credit rating system within the enterprise and provide certain support for the financing activities of SMEs in the actual operation process. In the internal management of enterprises, it is necessary to establish a corresponding management mechanism to scientifically manage the contents of the company's assets and intellectual property, and provide support for SMEs in their scientific and technological innovation and entrepreneurship. With the rapid development of modern science and technology, Internet technology can be used

In the medium-sized and small-sized enterprises, we have established a corresponding financing platform, developed a rational enterprise development strategy based on the trend of market economy development, expanded the financing channels for SMEs, and provided financial support for the further development of SMEs. 


\subsection{Activating social demand for technology services}

Clarify the relationship between the market and the government, introduce relevant professional organizations with strong professional skills and high service skills, and work with the government to supervise various service issues. We strongly support the expansion of business areas for service-oriented companies and improve their service capabilities. Here, we can start from the following aspects: implement outsourcing of government service projects, build a digital network platform for small and medium-sized enterprises, build smart cities, and implement various service projects. The government centralized procurement system and so on. Build a strong technology service brand and promote it to promote social awareness of the industry, promote the outsourcing process of information services, business and knowledge processes, and stimulate regional economic development for knowledge-intensive service industries. Urgent need.

\section{Conclusion}

The entrepreneurial activity of SMEs plays an irreplaceable role in the economic development of a country or region. It not only promotes the economic growth of the country or region, but also lays a material and spiritual foundation for its development. The establishment of support systems for entrepreneurial services in the US SMEs was studied, and their experiences and characteristics were summed up. This will serve as a reference for the construction of SME entrepreneurship service support systems. In the process of the establishment of SMEs' technological innovation and entrepreneurship service system, enterprises need to take into account the external environment for enterprise development. In the process of development, they must strive for government policy support and provide a good external development environment for SMEs' technological innovation and entrepreneurship development. To ensure the smooth progress of SMEs' technological innovation and entrepreneurship work. In the process of constructing a technology innovation and entrepreneurship service system, SMEs must continue to improve their internal service management mechanisms. In the course of the development of SMEs, they must establish a corresponding financing platform to address the difficulties of SMEs in developing financing difficulties and promote the development of SMEs.

\section{References}

[1] Loun K, Otto T, Riives J. Promotion of technology-based innovation and entrepreneurship[J]. Daaaminternationalvienna, 2009.

[2] Kim S S. Measuring firm-level innovation capability of small and medium sized enterprises with composite indicators[J]. Academy of Entrepreneurship Journal, 2013, 19(3):1-24.

[3] Beraha I, Stankovic I. The Role of Development Entrepreneurship and Small and Medium Entrerprises in Managing Structural Changes [J]. Book Chapters, 2013, 1:303-319.

[4] Booyens I. Are small, medium- and micro-sized enterprises engines of innovation? The reality in South Africa[J]. Science \& Public Policy, 2011, 38(1):67-78.

[5] Kärkkäinen H, Huizingh K R E, Conn S. International Journal of Entrepreneurship and Innovation Management[J]. International Journal of Entrepreneurship \& Small Business, 2013, 19(21):288-303.

[6] Zuzek D K. Barriers to development of the innovation potential in the small and medium-sized enterprises in Poland[C]// International Scientific Conference. 2014.

[7] Liu D, Guo Q, Wang W. Innovation Characteristics and Demand of the Poverty-Stricken Areas' Small and Medium-Sized Enterprises__Based on Qinba Continuous Destitute Areas' Survey Research[J]. Forum on Science \& Technology in China, 2016.

[8] Liu D X, Center I. Analysis and Enlightenment of SMEs Innovation and Entrepreneurship Management and Service Organization in the U.S[J]. Sci-tech Innovation and Productivity, 2016.

[9] Hua X, Wang Y, Wang M. The innovation and performance impacts of venture capital investment on China's smalland medium-sized enterprises[J]. China Economic Journal, 2016, 9(2):1-19. 
[10] Org Z. Promoting Innovation in New Ventures and Small- and Medium-Sized Enterprises[J]. World Scientific Books, 2017.

[11] Karadag $H$. The impact of industry, firm age and education level on financial management performance in small and medium-sized enterprises (SMEs): evidence from Turkey[J]. Journal of Entrepreneurship in Emerging Economies, 2017, 9(2):00-00.

[12] Teirlinck P. Configurations of strategic $R \& D$ decisions and financial performance in small-sized and medium-sized firms[J]. Journal of Business Research, 2017, 74:55-65.

[13] Tian Y. Research on the Development Environment of Human Resources Service Industry and Its Orientation[J]. Chongqing Social Sciences, 2016.

[14] Kallal R, Sakka O, Moujib B. The Impact of Corruption on Exports and Innovation in Small and MediumSized Enterprises: The Case of Tunisia[C]// International Conference on Entrepreneurship, Innovation and Development. 2018. 